\title{
PIETY, POLITICS, AND POST-ISLAMISM:
}

\section{Dhikr Akbar in Indonesia}

\section{Noorhaidi Hasan}

State Islamic University (UIN) Sunan Kalijaga, Yogyakarta, Indonesia

\section{Abstract}

Dhikr akbar has developed into a performance that provides the opportunity for the sharing of political ideas, thus helping to constitute and negotiate a new public sphere. It is one of the most remarkable developments in the public visibility of Islam in post-Suharto Indonesia. Involving reflexive actions which are significant in the construction of personal and social identity, the dhikr akbar has the ability to silently invoke relations, actions, symbols, meanings and codes, and also to bind in one symbolic package changing roles, statues, social structures and ethical and legal rules. An active religiosity which takes the form of peaceful, esoteric expressions, the dhikr akbar represents a new sense of piety. To some extent, it can be conceptualized as an alternative to religious fundamentalism, an outward-oriented activism tempted to change the society or existing system with one based on religion. Normally performed in a cultural space which attracts public esteem, it serves as a concentrated moment of communality and expression of a community's faith and, at the same time, a means of empowering political, social and economic networks.

Dhikr Akbar berkembang menjadi 'panggung' di mana gagasan politik dapat disemai, karena itu berperan dalam mengokobkan dan menegosiasi ruang publik. baru. Dhikr Akbar adalah salah satu bentuk ritual Islam di ruang publik yang berkembang pasca Orde Baru. Melalui aktifitas reflek.tif yang berperan dalam pembentukan identitas personal dan sosial, dhikr akbar mampu memunculkan relasi, aksi, simbol, makna dan kode, sekaligus untuke mempertemukan kesemuanya dalam satu bentuk simbol peran yang berubah, 
status, struktur sosial dan etika serta aturan bukum. Sebagai satu bentuke religiusitas aktif yang berbentuk corak Islam yang tenang dan berorientasi pada dimensi dalam -esoteris; dhikr akbar dapat disebut pula sebagai satu bentuk kesalehan baru. Bentuk kesalehan dapat juga merupakan bentuk keagamaan yang berbeda dengan fundamentalisme, yang berorientasi pada aktifisme dimensi luar dengan tujuan merubah masyarakat atau sistem yang berlaku dengan sistem yang dianggap Islami. Dhikr akbar yang biasanya diselenggarakan di ruang budaya menarik perhatian masyarakat. Kegiatan ini menjadi aktifitas yang mampu menyatukan komunalitas dan ekspresi agama, dan pada saat yang sama, mempertemukan jaringan politik, sosial, dan ekonomi.

Keywords: $d h i k r$, ritual, public sphere, active religiosity, post-Islamist piety

\section{A. Intorduction}

Dhikr akbar is one of the most conspicuous festive events in Indonesia today. It is a mass ritual programme which involves thousands of participants, male and female, clad in white dress. Frequently with presence of high-ranking officials, they gather in one big mosque and sit together to chant certain formulas of dhiker (confession of faith). Aired by private television channels, the dhikr akbar has attracted considerable attention among middle class in Jakarta and in provincial capitals like Semarang, Surabaya, Makassar, and Samarinda. Normally, it is organized in a specific context, such as, for instance, to commemorate Islamic holidays or anniversaries of certain provinces or cities. Its efflorescence has taken over the popularity of parades or carnivals and exhibitions that the government used to organize on such occasions in order to display and socialize "the achievements of pembangunan (development)."

Dhiker literally means the remembrance of God. It is a devotional act in Islam which includes the repetition of divine names, supplications and aphorisms from sections of the Qur'an or from badith (Prophetic traditions) literature. Prayer beads upon a string, known as tasbih, 99 in number which correspond to the ninety-nine names of God, are frequently used to keep tract of the number of recitations that make up the dhikr. Dhikris typified as a common practice among members of Sufi orders. They engage in ritualized dhikr ceremonies under the leadership 
of a murshid (Sufi guru). Each order or lineage within an order has one of more forms for group dhikr, the liturgy of which may include recitation, singing, instrumental music, dance, costumes, incense, meditation, ecstasy, and trance. The modes of Sufis' meditative dhikr include Dhikr al-Nafs (the soul remembrance of God), Dhikr al-Qalb (the heart remembrance of God), Dhikr al-Ruh (the spirit remembrance of God), Dhikr al-Sirr (the secret remembrance of God), Dhikr al-Khafi (the mysterious remembrance of God) and Dhikr al-Akhfa (the deeply mysterious remembrance of God), which reflect the basic orthodox Sufi philosophy. ${ }^{1}$

The dhikr akbar normally begins with a series of speeches delivered by high-ranking officials, themselves engaged in the programme sitting on the floor next to the ustadh (teacher) leading the recitation of the dbikr. Employing certain Qur'anic recital rhythms (qira'a), the ustadh leads the participants to chant verses from the Qur'an, La Ilaha Illa Allah (There is no God but God), Asma al-Husna (99 beautiful names of God), Ya Hayyu ya Qayyum (O Living and Giver of Life), Salawat (Asking God to send peace and blessings upon Muhammad), and Istighfar (Asking forgiveness from God), among other formulas of dhikr, fluently. Sometimes he takes the opportunity to give a short explication about the formulas, and call the participants to realize and repent for all sins they have committed. On certain moments he cries and expresses his regret on the current crises afflicting Indonesian Muslims and many participants follow to shed tears. Instead of blaming the West or "Zionist-Christian conspiracy" for inflaming the crises, like what Islamists are inclined to do, the ustadh insists on the need for self-introspection and often murmurs how diminutive they are before the omnipresence of God. Dhikr indeed is often claimed to be the only effective way to purify Muslims' hearts, and thus the solution to the spiritual, moral, cultural, and social problems facing the country. In such a non-confrontational style the dhikr akbar has transformed to be a sort of cultural performance projecting theatrical effects.

Dhikr akbar represents a new sense of piety which has developed among the emerging middle class Muslims. It is an active religiosity which

1 William Stoddart and A. R. Nicholson, Sufism: The Mystical Doctrines and the Idea of Personality (Delhi: Adam Publishers, 1998); William Stoddart, Sufism: The Mystical Doctrines and Methods of Islam (New York: Paragon House, 1986); William Chittick, Sufism: A Short Introduction (Oxford: Oneworld Publications, 2000). 
takes the form of peaceful, esoteric expressions. To some extent, it can be conceptualized as an alternative to religious fundamentalism, an outwardoriented activism tempted to change the society or existing system with one based on religion. In contrast to religious fundamentalism, piety is inward-oriented. It appears to be a willingness to work toward self purification and spiritual goals, with a particular emphasis on the ultimate salvation and love for God and the Prophet Muhammad, without necessarily being trapped into fanaticism or radicalism. Yet an active religiosity, piety is not so much a private matter as a public one. It is normally performed in a cultural space which attracts public esteem. In this context piety has intertwined with politics and culture.

No doubt, the dhikr akbar serves as a concentrated moment of communality and expression of a community's faith and, at the same time, a means of empowering political, social and economic networks. It is intriguing in this context to raise questions which will help us to understand more about the role of Islam in Indonesia's public sphere: What intersections of the sacred and the secular occur in the dhikr akbar? How has this ritual become so widespread, and what has contributed to its proliferation? What social and political meanings lie behind it?

\section{B. Public Religion}

The rising trend of popular piety indicates the revitalization of religion's public roles which theories of secularisation had assumed were becoming ever more marginal and irrelevant in the modern world. Religion is believed to have lost its social significance, to be measured in terms of the decline in the church attendance or other places of worship and in the amount of time and energy that people devote to other than mundane activities. Its central role in the public domain has allegedly been replaced by the rise of a scientific understanding of the world and of human origins. An overall consequence of this is that society had become firmly secular, and religion had become a matter of individual, private belief. ${ }^{2}$ However, there are compelling reasons for suggesting that secularisation theories have mistaken the past, and in so doing has misjudged the future. As Bryan Turner suggests in supporting anti-

${ }^{2}$ BryanWilson, Religion in Sociological Perspective (Oxford: Oxford University Press, 1982). 
secularisation theory, religion, especially Christianity, was indeed crucial to the feudal ruling class, but even more so to the urban industrial capitalist and the present society. ${ }^{3}$ In fact, religious institutions and organizations are likely to continue playing important public roles and continue to raise questions about the interconnections of private and public morality, thus challenging the legitimacy and autonomy of the primary secular spheres, including the state and the market economy.

In his assessment of the revitalization of religion in the modern world, Jose Casanova challenges the assumption that religion will tend to disappear with progressive modernization and necessarily endanger the differentiated structures of modernity. ${ }^{4} \mathrm{He}$ argues that religion undergoes a process of deprivatisation and repoliticisation, in which it abandons its assigned place in the private sphere and enters the undifferentiated public sphere of civil society to take part in the ongoing process of contestation, discursive legitimation, and redrawing of the boundaries. However, this does not mean that he refuses the validity of the secularisation thesis, especially in terms of the modern autonomous differentiation of the secular and the religious spheres. He believes that with the availability of primary public institutions, such as state and economy, modern societies do not need to be organized as "churches", in the Durkheimian sense, that is, as moral communities unified by a commonly shared system of practices and beliefs.

Nevertheless, the emancipation of the secular spheres from religious institutions and norms, in Casanova's opinion, does not prevent religion from entering the public sphere and the arena of political contestation. Religion not only participates in the very struggles to define and set the modern boundaries between the private and public spheres, but also plays a concrete role in directing the transition from authoritarianism to democracy and in intervening in the public debates, and thus contributing to the growth of civil society. Elaborating on Luckmann's thesis on The Invisible Religion, he suggests a conception of modern public religion which is compatible with liberal freedoms and with modern structural and cultural differentiation. From his point of view, religion which

${ }^{3}$ Bryan Turner, Religion and Social Theory: A Materialist Perspective (London: Heinemann Educational Books, 1983).

${ }^{4}$ Jose Casanova, Public Religions in the Modern World (Chicago: University of Chicago Press, 1994). 
accepts and embraces the modern principle of differentiation will also tend to accept the modern denominational principle of volunterism and will be in better position to adopt some form of evangelical revivalism as a successful method of religious self-reproduction in a free religious market. In Casanova's view, a given religion is to survive the modern process of differentiation provided that it relies on persuasion via public discourse, and thus address the common good in secular polities and motivate citizens into civic and political participation. ${ }^{5}$

Despite its focus on Spain, Poland, Brazil, and the United States, Casanova's observation is certainly not confined to Catholicism and Protestantism. Its horizons can be widened to include other parts of the world living with other religious traditions, including Islam, Judaism, and Hinduism. Eickelman, for instance, observes that a new sense of publicness is rapidly expanding throughout the Muslim world, owing to the growth of higher education, the increase ease of travel, and the proliferation of media and means of communication. ${ }^{6}$ The proliferation of mass education and communication in particular has led to an opening up of the political process and heightened competition for the use of the symbolic language of Islam. As a large segment of diverse Muslims has the opportunity to explain their goals in terms of the normative, globalized language of Islam and make their voices heard in public life, the notion of Islam as dialogue and civil debate is gaining ground.

Although these recent developments did not necessarily call the socalled public sphere into being, they contributed significantly to reshaping a sense and structure of public that was already available. An embryo of "public Islam" emerges and poses a challenge to the secularist definition of the boundaries and content of the public sphere. It provides spaces for encounters on different levels and informs individual and collective strategies of cultural dialogue. ${ }^{7}$ In fact, the transparency engendered by

${ }^{5}$ For a critical review on Casanova's thesis of public religion, see Armando Salvatore, "Public Religion, Ethics of Participation, and Cultural Dialogue," in Abdul Aziz Said, Mohammaed Abu-Nimer and Meena Sharify-Funk (eds), Contemporary Islam, Dynamic, Not Static (London and New York: Routledge, 2006), pp. 83-100.

${ }^{6}$ Eickelman, Dale. "Islam and the Language of Modernity," Daedalus 129 (2000): 119-135.

7 Armando Salvatore and Dale Eickelman, "Public Islam and the Common Good," in Armando Salvatore and Dale F. Eickleman (eds), Public Islam and the Common 
the recent developments-including new interactive media such as the Internet and satellite television - increases the scope, intensity, and forms of involvement in a multiplicity of overlapping public spheres. New actors who bear no religious authority in a traditional sense emerge and provide alternatives to thinking of Islamic action in immediate social and political terms. Utilizing the new interactive global media they create a synthesis through a sort of cultural hybrid practices, in such a way that they package Islam and offer it for mass consumption.

\section{B. New Ulama, New Audience}

The dhikr akbar constitutes first and foremost an urban phenomenon which facilitates an interactive process between new religious intellectuals and audiences — including well-educated cosmopolitans like professionals, technocrats and functionaries. Most of the ustadhs known for their expertise in leading the recitation of the dhiker are newcomers in the religious discourse and practice in Indonesia. Although some are familiar with classical commentaries, they are not religious scholars (ulama) in a strict sense, meaning those who are trained exclusively in religious subjects offered in traditional madrasas (Islamic school) or other Islamic teaching centres. In many senses they are very different from the ulama, who use to hold the right and duty to make sure that all major developments in politics and society are in conformity with God's commands on the grounds that they were most knowledgeable in the sciences of the Qur'an and the traditions of the Prophet. ${ }^{8}$ In fact, the majority of the ustadhs are alumni of national education systems, who acquired their religious knowledge through self-study or participation in small discussion groups. But interestingly perhaps, they tend to be more interested than their classic predecessors in linking religious teachings to the nonreligious - educational, social, economic, and political spheres. They are also concerned with expanding economic development, adopting high technology, and using new media as a means to communicate their visions and messages.

One such example is Muhammad Arifin Ilham known for his

Good (Leiden \& Boston: Brill, 2004), pp. xi-xxv.

8 Muhammad Qasim Zaman, The Ulama in Contemporary Islam (Princeton: Princeton University Press, 2007). 
distinguished tone, with the fluctuating pitch and tenor in his speech patterns and fluency in reciting the Quran. He exemplifies a charismatic, young preacher capable of utilizing a full range of media for the benefit of his public appearances. His name began skyrocketing when he led a programme called "Reciting Dhiker for My Country" which took place in Indonesia's largest mosque, Istiqlal, in August 2003, with the presence of the then Vice President of Indonesia, Hamzah Haz, and a number of other high-ranking officials. Ilham has since regularly appeared on various national television channels presenting short lectures on Islam. He also has been the host of Saturday's morning lecture at TPI, a private television channel and of several radio programmes. A graduate of political science at the National University of Jakarta, Ilham forged his insights into Islam when he enrolled in a modern Islamic boarding school in Jakarta. An experience to win speech competitions at different levels encouraged him to embark on a career as a religious preacher as early as his undergraduate years at the university.

Ilham is the founder of Majlis Az-Zikra, a sort of holding company which incorporates several business enterprises. Under its auspices, there is Adzikra Penaraya, which focuses on publishing books, booklets, pamphlets, and monthly Az-Zikra, which appears to be the mouthpiece of the organization. Although the editorial board of this periodical consists of conservative Muslim leaders like Muslih Abdul Karim, Abu Bakar Ba'asyir, Salim Segaf al-Juhri, Didin Hafiduddin, Ja'far Umar Thalib, Habib Rizieq Shihab, and Toto Tasmara, among other names, its tendency to side with progressive Muslims triggered a protest from conservative Muslims and like-minded individuals. A prolific conservative columnist, Adian Husaini, accused the periodical of being trapped in secularism and Orientalism. ${ }^{9}$ In fact, in one issue on Islamic media Az-Zikra stridently criticized Islamist books and periodicals, while pointing out their preference to echo the works by progressive Muslims associated with Paramadina. The latter is known as a leading Islamic NGO set up by the most prominent Indonesian theologian Nurcholish Madjid in order to disseminate plural Islam. ${ }^{10}$ In addition to this, it runs

${ }^{9}$ Adian Husaini, "Infeksi Sipilis di Majalah Azzikra," Suara Hidayatullah (October, 2005).

${ }^{10}$ Noorhaidi Hasan, "In Search of Identity: the Contemporary Islamic Communities in Southeast Asia," Studia Islamika 7, 3: 2002, 67-110; Julia Day Howell, 
a production house concerned with the production of sermon cassettes and Islamic soap operas on digital video discs. True to its ambition to empower Muslim economy, Majlis Az-Zikra set up several business lines, including AzDzikra travel agent and Tim Berkah Alma, responsible for providing special packages of holy tours and producing Mapinda fresh water, respectively. Recently it built an "Islamic" housing complex on a 50-hectare land in Bogor, near Jakarta, under the umbrella of Sentul Adzikra Estates.

Ilham actually followed in a step Abdullah Gymnastiar, more commonly referred to as Aa Gym, had initiated. Aa Gym is the founder of the Darut Tauhid pesantren in Bandung, West Java, in 1987, and a young talented preacher trained in economics and technical courses at the Padjadjaran University and Ahmad Yani University respectively, both in Bandung. Being more interested in Islamic knowledge, however, he never finished his degree. Instead, he studied Islam with a number of traditional 'ulama. Aa Gym claims that the Darut Tauhid's primary mission is to facilitate the development of Islamic educational, economic, social, and cultural activities. It aspires to become a miniature of society where Islamic teachings can be practiced and enriched by education, training, management, art and culture, economy and technology initiatives and its benefits can be felt by the Muslim umma. Under the auspices of the MQ corporation, Aa Gym has systematically developed business-oriented activities, extolling its slogan that the economic development is the primary pillar of devotion to God.

The basic doctrine of Darut Tauhid includes dhikr, fikr (thinking), and ikbtiyar (free choice). Among the Darut Tauhid members dhiker is the primary principle on which Muslims should rely, in the sense that God is the only focus and target in Muslim activities. Aa Gym, however, argues dhikralone is not enough; Muslims should also think and optimize Muslim initiatives and efforts to compete in a challenging era. Dhike, fiker, and ikhtiyar are thus the three key principles that should be taken into account by all members of the Darut Tauhid's community. This method is called by Aa Gym "Manajemen Qalbu" (the management of heart).

\footnotetext{
"Sufism and the Indonesian Islamic Revival," The Journal of Asian Studies 60, 3: 2001, 701-29; Andi Faisal Bakti "Paramadina and Its Approach to Culture and Communication: An Engagement in Civil Society," Archipel 68: 2004, 315-41.
} 
The basic notion is to manage and maintain purity of heart in the way of knowing God. With his characteristic style—baju koko, sarong and typical (Aa Gym) turban — and admirable rhetoric, he delivers his sermons, which are rather emotional and frequently move people to tears. He believes that spiritual values such as patience, generosity, resignation and honesty, once nurtured, will pour out of people's hearts. ${ }^{11}$ Only recently his reputation began significantly declining, primarily as a result of his decision to take a second wife.

Another young, popular preacher of this kind, Jeffry al-Buchori, began his career just recently but succeeded in putting himself on the map of the most popular Indonesian religious figures. With his outstanding rhetoric and ability to recite the Qur'an fluently he mesmerizes congregations of Islamic sessions and religious gatherings held on various occasions and aired by different national television channels. He is known as a friendly religious teacher (ustar, gaul), who prefers to address his congregation with "Hello Friends!" or "Hello Choy!" Wearing his distinctive baju koko motifs and white cap, he also appears on television screens almost every day, delivering short religious lectures full of improvisations. Sometimes he sings and laughs and another time he cries. He works with the slogan "have fun with religious wisdom". Under the auspices of the Majlis Mim, he serves as the host of numerous religious programs on television, including "I like Monday" aired every Monday. It is important to note that he grew up as a delinquent youth addicted to drugs. Having completed his primary and secondary education in an Islamic school in Tangerang, he went to a private communication school in Jakarta to study broadcasting. Here he became acquainted with night-club life spending most of his time in discotheques, casinos and other reputed dens of iniquity. He began to realize his delinquencies and decide to return to a normal life only in 2000 . He made his debut on television in 2003 after having delivered religious lectures from one mosque to another.

These new religious intellectuals may not be as literate as those of the past, but they are certainly more able to manipulate symbols and

11 C.W. Watson, "A Popular Indonesian Preacher: the Significance of AA Gymnastiar," The Journal of the Royal Anthropological Institute 11, 4: 2005, 773-92. 
rituals and to represent the mass society of today. They articulate their concerns in a contemporary fashion, utilizing the new communicative means. In their hands, Islam appears to be no longer dominated by long homilies on religious doctrines and the life in the hereafter, or calls for a return to true Islam which nurtures some hatred of global popular culture trends, which is claimed to have led to the moral decline of Muslims and threatened Islamic cultural values, and which is thus conventional, rigid, and exclusive in character. Islam is now imbued with practical messages about the way to live in harmony and styled in accordance with (upper) middle class and new wealth's appetite, symbolized by religious insignia of all kinds. Such messages are disseminated through Islamic teaching packages at five-starred hotels, expensive tours of Islamic holy sites, Islamic soap operas on television, or advertisements in newspapers and periodicals exhibiting beautiful girls wearing colourful, trendy headscarves (jilbab). In this way Islam has become chic and transformed from simply a marker of personal devotion into a sign of socioeconomic status, but less than a political statement. ${ }^{12}$

The dhikr akbar represents a creative effort made by the new religious intellectuals to comply with the interest and lifestyle of the new religious audiences. They are an emerging Muslim middle class which thrived as an impact of the government's mass education programme enabling a large number of Indonesian Muslims to pursue a higher education. During their enrolment at university education in the 1980s and 1990s, many of them witnessed the explosion of Islamic revival, evidenced in an increase in the wearing of headscarves among university students and a proliferation of Islamic literature by Islamist thinkers such as Hasan al-Banna, Abul A’la al-Mawdudi, Sayyid Qutb, Ali Syariati, and Murtadha Mutahhari. Although the majority of them were not necessarily absorbed in the current of Islamic activism active in calling for a change in the existing system, they were generally obsessed with the zeal to demonstrate their Islamic identity more explicitly. After completing university education many of them have spread into various sectors of governmental services and modern business structures and entered a

12 Jenny B. White, "Islamic Chic," in Istanbul, Between the Global and the Local (Lanham, Boulder, New York, and Oxford: Rowman \& Littlefield Publishers, 1999), pp. 77-91; Mona Abaza, "Markets of Faith: Jakartan Da'wa and Islamic Gentrification," Archipel 67: 2004, 173-202. 
new status as urban middle class. The desire to demonstrate both their Muslimhood and new status as members of the (upper) urban Muslim middle class paralleled with the ability of the new religious intellectuals to package Islam for mass consumption. Islam is now available in far more accessible format, open to everyone. It is precisely in this intersection the dhikr akbar has developed into a phenomenal urban religious landmark of present-day Indonesia.

The trend which initially developed among urban middle class has radiated into a large segment of Indonesians and crossed over the existing class borders. It provided an alternative and a credible route for mobility, especially for the urban masses who have been exhausted with overcrowded urban neighbourhoods that the state has failed to organize either with respect to infrastructure or in terms of cultural or political structures. Exacerbating their feeling of dispossession is the climate of widespread corruption, economic stagnation, and bureaucratic incompetence, which have overshadowed the historical course of modern Indonesia. The government has seemingly failed to balance the supply of and demand for workers, engendering rising competition in job markets. In an atmosphere of resilient competition fanned by the winds of economic liberation the dhikr akbar appears to be a channel through which basic social and political questions could be articulated in an elegant way.

\section{Post-Islamist Piety}

The dhikr akbar conceals a clear shift from the earlier emphasis of Islamism on Islamist polity to one on personal piety. Its participants are mostly not Muslims interested in Islamist's agenda of reforming Islam and society in a total manner, and blaming the existing secular system as that had brought the Muslim world into nothing than brutality, a lack of justice, corruption, and disasters, or explicitly demanding the replacement of the existing system with one based on the shari'ah. Although they have a kind of objective consciousness about the meaning of being Muslim and thereby attempt to implement it at a personal level, they stop questioning the compatibility between Islam and modernity, for example. They project a pluralist vision of Islam and believe that Islam is necessary modern if implemented in a proper manner. 
Asef Bayat conceptualizes this phenomenon as post-Islamism, a conscious attempt to conceptualize and strategize the rationale and modalities of transcending Islamism in social, political, and intellectual domains. ${ }^{13}$ Representing "an endeavour to fuse religiosity and rights, faith and freedom, Islam and liberty," it renders religion into a plural reality with multiple meanings and accommodates aspects of democratization, pluralism, multiculturalism, and human rights. ${ }^{14}$ Bayat further argues that:

Post-Islamism serves primarily as theoretical construct to signify change, difference, and the root of change. The advent of post-Islamism does not necessarily mean the historical end of Islamism. What it means is the birth, out of the Islamist experience, of a qualitatively different discourse and practice. ${ }^{15}$

As far as I am concerned, post-Islamism can be seen as an alternative which gains ground amidst the failure of the project that attempts to position Islam as a political ideology and thereby change the political landscape of Muslim states. The experiences of many Muslim states confirm that the project has instead stigmatized Islam and transformed it into a sort of enemy of the modern civilization. No doubt, it emerges as a sort of hybrid practice, a process of cultural transactions that reflects how global cultures are assimilated in the locality. ${ }^{16}$ Through the instruments of globalization, including the print media, radio, television, internet, and mobile phone, Muslims are in fact becoming closer to the global leisure market which commodifies and regularizes the avant-garde trends and practices. Being a "good' Muslim is thus possible without necessarily sacrificing the privileges he or she has enjoyed from globalization.

Jenny B. White emphasizes that post-Islamism is the evidence of the rise of a personalized Muslimhood, which allows one to demonstrate his religious identity through bodily purchased practices and goods,

13 Asef Bayat, "What is Post-Islamism," ISIM Review 16: 2005, p. 5. See also Asef Bayat, Making Islam Democratic. Social Movements and the Post-Islamist Turn (Stanford: Stanford University Press, 2007), 10-1.

${ }^{14}$ Ibid.

15 Bayat, "What is Post-Islamism", p. 5.

16 Carcía Canclini, Hybrid Cultures (Minnepolis, MN: University of Minnesota Press, 1995), p. 25 
thus apart from political engagement and its religious mooring. ${ }^{17}$ With the growth of intermediate class capable of utilizing "Islamic" market opportunities for their business expansion and packaging Islam for mass consumption, the market and media become increasingly critical in defining the identity of a "Muslim". Everything labelled "Islamic" is largely advertised and sold both in traditional markets and in the Muslim section of luxury goods department stores, ranging from typical Muslim fashions, such as jilbab (headscarf) for women and baju koko (Muslim shirts) for men with their trendy and colorful styles to special makeup and skin products with the halal label as well as various kinds of pop and hip-hop Islamic music. It is precisely via the marketplace and media, Muslimhood has become fashionable.

The Muslimhood model provides both a challenge and an opportunity to rethink the established boundaries between the private and the public. It has come up short against the seemingly immovable boundaries, which hardly see any compromise between the religious and the public. These boundaries become increasingly irrelevant when religious institutions undergo a process of differentiation and institutional specialization, which seemingly encourages religious roles to be specialized within the individual conscience. Individual can thus choose a widened range of options among a wide assortment of religious representations, traditional religious ones as well as secular new ones, manufactured, packaged, and sold by specialized service agencies. ${ }^{18}$ The free choice, in turn, provides the individuals an opportunity to patch together the religious fragments into a subjectively meaningful whole and transform them into a powerful symbol to act in public.

\section{Ritual and Politics}

The dhikr akbarappears to be one form of mass ritual which is likely to serve political purposes in modern societies. As many anthropologists suggest, ritual has become an indispensable part of modern political life. For politics everywhere has a fundamental ritual and symbolic aspect.

${ }^{17}$ Jenny B. White, “The End of Islamism? Turkey's Muslimhood Model,” in Robert W. Hefner (ed.). Remaking Muslim Politics (Princeton: Princeton University Press, 2005), pp. 87-111.

${ }_{18}$ Jose Casanova, Public Religions, pp. 36-7. 
David Kertzer, for instance, contends that politics are essentially about ritual and symbolism and particularly crucial in legitimating dominance, not just in the eyes of the rulers, but in the eyes of the ruled as well. ${ }^{19}$ Through ritual aspiring political leaders struggle to assert their rite to rule, incumbent power holders seek to bolster their authorities, and revolutionaries try to carve out a new basis of political allegiance. Exploring the power of ritual to both legitimize and delegitimize existing regimes, Kertzer goes beyond Geertz and Bloch, who argued that through symbols ritual primarily functions to nurture and express the political stability of stratified societies upon which the legitimacy of the system and its power holders depend. ${ }^{20}$

The importance of rituals for politics stems from the fact that politics is expressed through symbolism. Symbols give people a way of understanding the worlds and interpreting what they see, and, indeed, what they are. Rituals play a major role in dramatizing and glamorizing the symbols, whereby elites make claims to power and send messages to the public about the criteria to establish who has authority and who does not. Through rituals too their political contenders question the legitimacy of the existing system and those in power. Rituals are thus far more than means of communicating the result of political struggles. They have their own power and are themselves an important field of political struggle saturated with emotion. In his seminar work on social drama Victor Turner argues that ritual is precisely a mechanism and powerful means of uniting symbols of social reality with strong emotional stimuli. ${ }^{21}$

Indeed, the dhiker akbar resembles a social drama which involves physiological stimuli and the arousal of emotions by which people participate in it see themselves as playing certain roles. Islamists, secularist intellectuals, and politicians from across the ideological spectrum come to join in the programme and give interpretations and meanings over their own participation. It has become a market of faith which, through symbols, facilitates negotiations and-social, political, and cultural-

${ }^{19}$ David Kertzer, Ritual, Politics, and Power (New Haven and London: Yale University Press, 1988).

${ }^{20}$ David N. Gellner, "Religion, Politics, and Ritual: Remarks on Geertz and Bloch,” Social Anthropology 7, 2: 1999, 135-53.

${ }^{21}$ Victor Turner, Drama, Fields, and Metaphors (Ithaca: Cornell University Press, 1974). 
transactions not only among individuals participating but also with larger social groups, or precisely society at large, watching the programme via television channels. Though all the participants are clad in white dress and sitting on the floor, demonstrating their willingness to absorb into some sort of mechanical solidarity, in the Durkheimian sense, pledged to mutual support and cooperation, they are actually civic groups who have different interests, which are not necessarily political, but often personal. They gathered to capture a shared common denominator that may not represent everyone's views in their entirety, but enough to show up a spirit of reconciliation.

The dhikr akbar has become one of the main arenas in which various forces of the Indonesian civil society have the opportunity to send messages about their commitment to deal with the current uncertain-economic, political, and social—situation, which began with the eruption of the Asian economic crisis in 1997. Not only did this crisis instigate the meltdown of the Indonesian currency, mass dismissals, and unemployment. It also brought about the collapse of the New Order regime which had been in power for over thirty-two years. No doubt, the collapse of the regime facilitated the opening of the Indonesian public sphere, and with this, a new hope for the better future of the country. However, nearly a decade after the fall of Suharto Indonesia cannot totally detach itself from the impact of the crisis. Poverty, unemployment and corruption have consistently overshadowed the everyday life of Indonesians. A sense of frustration, therefore, overwhelmed the majority of them. This feeling intensified as different kinds of disasters, one after another, have come to hit various Indonesian provinces.

All these things have had certain impact on the legitimacy of the country's political leadership. People began questioning about the commitment the government had made to quickly curb the protracted impact of the crisis and bring justice and welfare for the people. In this context the dhikr akbar appears to be one of the remaining effective communicative channels that can be attempted between the government and the people. Vibrant voices of the ustadh when reciting $d b i k r$ and explaining some of its meanings represent both participants' concern about the on-going crisis and their expectation for significant changes. Tears dropping from their eyes may be interpreted as a sign of their 
regret of the government, but also their understanding about the government's limitations to cope with mounting delicate problems facing the country. While hope and optimism are expressed that with purified and unified hearts God should assist them to get rid of the problems, the participants are reminded of the nothingness of human-beings before the omnipresence of God.

The dhikr akbar provides an arena in which political leaders at different levels identify themselves with certain symbol and create the public impression that they are not simply power holders, but also part of community ready to struggle for justice, equity, and the general good. Creating a symbol, or more commonly, identifying oneself with a popular symbol, is in fact a potent means of gaining and keeping power. By staging a dramatic presentation in the dhikr akbar they seek to promulgate the view of the political situation they would like the general population to hold. It is far more likely for them to achieve a deeper and more lasting impression through this way than they are by simply asserting it verbally. The drama not only constructs a certain view of the situation, but it also engenders an emotional response that associates notions of right and wrong with the elements in this view. It is, indeed, a moral drama, not just an instructional presentation.

\section{E. Media and Entertainment}

The dhiker akbar has apparently never been pervasive as it is, if not bolstered by the development of a communication technology. Thanks to new satellite facilities television has become available not only in the big cities of Indonesia but also in the villages of the countryside and outermost islands. This expanding communication technology achieved further endorsement when Suharto introduced some deregulation packages on public broadcasting which allowed private companies, mostly of his own cronies, to set up new television channels. After his fall new players of media business have arisen and contributed to a further expansion of private television channels, whose number has multiplied over the last five years. In their race to book rating ranking and thus advertisement portions, the channels seek to offer various kinds of pro-market broadcasts, including religious programmes. New religious programmes are introduced and the existing ones have creatively been 
modified in order to attract broader audience.

Television has not been the only medium for the widespread distribution of religious programmes, however. Video cassettes, compact discs and digital video discs came to furnish the Islamic media market with handy religious homilies, religious preaching, music, and soap operas. For those who prefer to spend time browsing in the cyberspace, they do not need to collect all the materials; they can simply go to thousands of "Islamic" websites offering different, often competing, versions of Islam. Facilitated by the advancement of mobile phone technology, the so-called "Cellular Quran" recently came to offer a service for customers to listen to the recitation of certain Qur'anic verses, plus explanation and wisdom that can be explored from them. There is also a mobile dictionary of Islam called "Islamic pocket", which facilitates its bona vide users with practical information about Islam.

It goes without saying that the new communication technology facilitates the rise of new religious actors who remain otherwise local in their reputation in the national stage of Indonesia. Through television screens, their influence goes beyond their respective domains to reach remote areas in villages of the countryside. The mastery of classical knowledge of Islam is no longer a dominant factor in shaping their public profile. It is more determined by their ability to perform before the camera and communicate with audience through a multiplicity of religious programmes they offer. The media itself will reconsider the sustainability of a programme when the position of its rating ranking and thus its viewers, declines. In this context, the new religious actors are required to make real contacts with their mass following through colossal programmes like the dhikr akbar.

Through the circulation and diffusion of particular symbol, the dhikr akbar presents a sacred atmosphere which unites emotion between the ustadh and participants and among the participants themselves. It constitutes a complex web of discursive, symbolic and experiential practices which appear to be one example in which Islam constitutes no longer simply a set of rituals and doctrines, but also about lifestyle, modesty and enjoyment. It has become commodified in such a way that it transformed religious doctrines, symbols, and values into free-floating signifiers to be consumed like anything else. The market value of this 
ritual is particularly linked in its capacity of evoking particular religious experiences through the corporeal and emotional sensations that they induce in the participants. Formulas of dhikr they are chanting provide narratives that can be elaborated as scenes, gestures, or, building on a powerful religious consciousness, in order to give a framework of understanding to particular forms of experience.

At the same time, the dhikr akbar enables people to find an alternative entertainment in a mass religious programme aired by television channels. Like anyone else, well-educated cosmopolitans and lower urbanites want to be relieved and diverted from the stress of the increasingly indifferent urban life. They decide to participate in particular religious programmes not with the desire to be challenged intellectually, religiously, or morally. They expect and want such programmes principally to entertain them. And by "entertainment" they mean leisure-time fun or diversion. This also holds true for viewers who follow the programme through television screens. They turn on the tube with playful expectation. Herein lies the significance of the dhiker akbar as one form of piety and entertainment altogether which can be enjoyed by many people. Through theatrical effects it elicits, the dhikr akbar has indeed become an entertaining drama. This type of live programme is truly engaging fare-far more so than most preaching or Qur'anic teaching. In this context, the dhikr akbar has helped to transform Islam from a mosque into an entertainment and from historic faith into a popular religion.

\section{F. Conclusion}

The growing popularity of the dhikr akbar and similar programmes, which coincided with the fading influence of Islamic militancy tide which called for the comprehensive application of the shari' $a$ and jihad, indicates the shift in the way that Indonesian Muslims express and negotiate their religious and political identity in the current Indonesian public sphere. In contrast to the Islamic militant tendency which pursued its struggle through violent discourse and actions, thus contradicting the modern denominational principle of volunterism which informs public rationality, the dhikr akbar appears to be one form of piety which emphasizes a personalized Muslimhood. Its participants are not those interested in Islamist's agenda of explicitly demanding the replacement of the existing 
system with one based on the shari'ah. Although they have a kind of objective consciousness about the meaning of being Muslim, they saw an inherent compatibility of Islam with modernity. This Muslimhood model goes hand-in-hand with the process of globalization, which has made Islam fashionable and available in far more accessible format, open to everyone.

The dhikr akbar is one example which indicates how piety has become a complex web of discursive, symbolic and experiential practices which facilitate the way in which Muslims express their concern with the on-going uncertain situation and thus involve in debating public issues. Facilitating a process of negotiations and-social, political, and cultural - transactions among a large number of Indonesian Muslims the dhikr akbar has become a market of faith invested by political authorities in order both to maintain their legitimacy and to create the mechanisms of governance through religion. Through the ritual of chanting dbiker together in the dhiker akbar the spirit of rebellion has been replaced with submission, anger and violence with peace, and conflict with solidarity and togetherness. 


\section{BIBLIOGRAPHY}

Abaza, Mona, "Markets of Faith: Jakartan Da'wa and Islamic Gentrification," Archipel 67: 2004, pp. 173-202.

Bakti, Andi Faisal, "Paramadina and Its Approach to Culture and Communication: An Engagement in Civil Society," Archipel 68: 2004, pp. 315-341.

Bayat, Asef, "What is Post-Islamism," ISIM Review 16: 2005.

Canclini, Carcía, Hybrid Cultures, Minnepolis, MN: University of Minnesota Press, 1995.

Casanova, Jose, Public Religions in the Modern World, Chicago: University of Chicago Press, 1994.

Chittick, William, Sufism: A Short Introduction, Oxford: Oneworld Publications, 2000.

Eickelman, Dale, "Islam and the Language of Modernity," Daedalus 129, 2000, pp 119-35.

Gellner, David N., "Religion, Politics, and Ritual: Remarks on Geertz and Bloch," Social Anthropology 7, 2: 1999, pp. 135-53.

Hasan, Noorhaidi, "In Search of Identity: the Contemporary Islamic Communities in Southeast Asia," Studia Islamika 7, 3: 2002, pp. 67-110.

----, "September 11 and Islamic Militancy in Post-New Order Indonesia," in K.S. Nathan and Mohammad Hashim Kamali (eds), Islam in Southeast Asia: Political, Social and Strategic Challenges for the $21^{\text {st }}$ Century, Singapore: ISEAS, 2005, pp. 301-22.

----, Laskar Jihad: Islam, Militancy, and the Quest for Identity in Post-New Order Indonesia, Ithaca: Southeast Asia Program Publications, Cornell University, 2006.

Howell, Julia Day, "Sufism and the Indonesian Islamic Revival," The Journal of Asian Studies 60, 3: 2001, pp. 701-29.

Husaini, Adian, "Infeksi Sipilis di Majalah Azzikra," Suara Hidayatullah, October, 2005.

Kertzer, David, Ritual, Politics, and Power, New Haven and London: Yale 
University Press, 1988.

Salvatore, Armando, "Public Religion, Ethics of Participation, and Cultural Dialogue," in Abdul Aziz Said, Mohammaed Abu-Nimer and Meena Sharify-Funk (eds.), Contemporary Islam, Dynamic, Not Static. London and New York: Routledge, 2006.

---- and Dale Eickelman, "Public Islam and the Common Good," in Armando Salvatore and Dale F. Eickleman (eds.). Public Islam and the Common Good, Leiden \& Boston: Brill, 2004, pp. xi-xxv.

Stoddart, William and A. R. Nicholson, Sufism: The Mystical Doctrines and the Idea of Personality, Delhi: Adam Publishers, 1998.

Stoddart, William, Sufism: The Mystical Doctrines and Methods of Islam, New York: Paragon House, 1986.

Turner, Bryan, Religion and Social Theory: A Materialist Perspective, London: Heinemann Educational Books, 1983.

Turner, Victor, Drama, Fields, and Metaphors, Ithaca: Cornell University Press, 1974.

Watson, C.W., "A Popular Indonesian Preacher: the Significance of AA Gymnastiar," The Journal of the Royal Anthropological Institute 11, 4: 2005, pp. 773-92.

White, Jenny B., "Islamic Chic," in Islanbul, Between the Global and the Local, Lanham, Boulder, New York, and Oxford: Rowman \& Littlefield Publishers, 1999, pp. 77-91.

----, “The End of Islamism? Turkey's Muslimhood Model," in Robert W. Hefner (ed.). Remaking Muslim Politics, Princeton: Princeton University Press, 2005, pp. 87-111.

Wilson, Bryan, Religion in Sociological Perspective, Oxford: Oxford University Press, 1982.

Zaman, Muhammad Qasim, The Ulama in Contemporary Islam, Princeton: Princeton University Press, 2007. 